31. Filatova, O. (2012). Terminological verification of authorship: "system-subject method" by B. Corman. Scientific works. Literary Studies. Issue. 193. Vol, 119-122. [in Ukrainian].

32. Sereteli K. (1981). Otar loseliani Trilogy.Cinopanorama. V. Fomin (Ed). Issue 3. Moscow: Iskusstvo, pp.144 -161 [in Russian].

33. Cherkov, H. (2017). On-screen Image: Information Content. International Teaching and Graduate Conference, dedicated to the 120th anniversary of Ukrainian cinema, (pp. $47-49$ ). Kyiv: KNUTKiT imeni I. K. Karpenka-Karoho [in Ukrainian].

34. Shevchuk, O. (2002). Ukrainian and world cinema. Ukrainian and foreign culture. Kyiv [in Ukrainian].

35. Introductionto Andre Bazin, Part 2: Styleas a Philosophical Idea. Retrieved from: http://offscreen.com/view/bazin3. [in French].

Стаття надійшла до редакції 10.05.2019 p.

УДК 76.041:008(477)

Солярська-Комарчук Ірина Олегівна

кандидат філософсььких наук, доцент, доцент кафедри мистецтвознавчої експертизи

Національної академії керівних кадрів культури і мистецтв

ORCID 0000-0002-3229-9153

irasolarsky@gmail.com

\title{
ОСОБЛИВОСТІ ЗОБРАЖЕННЯ СВЯТО-ІЛЛІНСЬКОЇ ЦЕРКВИ В СУБОТОВІ У РОБОТАХ ХУДОЖНИКІВ
}

\begin{abstract}
Метою дослідження є аналіз особливостей зображень Іллінської церкви з с. Суботів у живописних творах зарубіжних та вітчизняних художників XVIII - початку XX століть. Методологія дослідження полягає у застосуванні мистецтвознавчого, культурологічного та біографічного підходів для аналізу творів художників, котрі своїм зображенням Іллінської церкви наголошували на її культурно-мистецькій унікальності. Наукова новизна полягає у виявленні інтерпретації художніми засобами мистецької та історико-культурної цінності Свято-Іллінського храму як важливої пам'ятки резиденції Б.Хмельницького. На основі розгляду творів художників О.Осипова, Т.Шевченка, К.Пржичиховського, С.Васильківського та етнографа де ля Фліза з'ясовується архітектурна достовірність пам'ятки (первинний вигляд, відсутність авторських домислів), котра є важливим фактором для проведення відновлювально-реставраційних робіт, мистецтвознавчих та культурологічних досліджень. Висновки. Здійснений аналіз художніх творів, присвячених богдановому храму у Суботові, засвідчує, що гравюра О.Осипова та акварель Т.Шевченка $€$ найбільш точними у передачі первинного вигляду будівлі. Окрім того, вони демонструють особливу стилістику цієї архітектурної пам'ятки, сформовану на основі переосмислення місцевих традицій храмового будівництва під впливом західноєвропейського бароко та тогочасних оборонних потреб.
\end{abstract}

Ключові слова: храм, бароко, зображення, гравюра, акварель.

Солярская-Комарчук Ирина Олеговна, кандидат фрилософских наук, доцент Национальной академии руководящих кадров культуры и искусств

Особенности изображения Свято-Ильинской церкви в Субботове в работах художников

Целью работы выступает анализ особенностей изображения Ильинской церкви с. Субботов в живописных произведениях зарубежных и отечественных художников XVIII - начала XX веков. Методология исследования заключается в использовании искусствоведческого, культурологического и биографического подходов для анализа произведений художников, которые своим изображением Ильинской церкви акцентировали внимание на ее культурно-художественной уникальности. Научная новизна состоит в выявлении интерпретации средствами искусства художественной и историко-культурной ценности Свято-Ильинского храма в качестве важного памятника резиденции Б.Хмельницкого. На основе рассмотрения произведений художников А.Осипова, Т.Шевченка, К.Пржичиховского, С.Васильковского и этнографа де ля Флиза выясняется архитектурная достоверность памятника (первичный вид, отсутствие авторских домыслов), что важно для проведения восстановительнореставрационных работ, искусствоведческих и культурологических исследований. Выводы. Проведенный анализ художественных произведений, посвященных богданову храму в Субботове, свидетельствует, что гравюра А.Осипова и акварель Т.Шевченка более точно передают первичный вид здания. Кроме того, они демонстрируют особенную стилистику этого архитектурного памятника, которая сформировалась на основе переосмысления местных традиций храмового строительства под влиянием западноевропейского барокко, а также оборонных потребностей того времени.

Ключевые слова: храм, барокко, изображение, гравюра, акварель. agement

Solarska-Komarchuk Irina, Ph.D.in of Philosophy, docent of the National Academy of Culture and Arts Man-

Features of the image of the Church of St. Elyinsky in the Subotov in the works of artists

The purpose of the article. The aim of the work is the analysis of the features of the image of the llinsky church. Sabbaths in the paintings of foreign and domestic artists of the XVIII - early XX centuries. Methodology. The research methodology is based on the use of art history, cultural, and biographical approaches to the analysis of the

() Солярська-Комарчук І. О., 2019 
works of artists who, with their image of the Elijah Church, focused on its cultural and artistic uniqueness. Scientific Novelty. The scientific novelty consists of revealing the interpretation using the art of artistic, historical, and cultural value of the St. Elias Church as an important monument to the B. Khmelnitsky residence. Based on the consideration of works by artists A. Osipov, T. Shevchenko, K. Przhichihovsky, S. Vasilkovsky, and ethnographer de la Fliz, the architectural accuracy of the monument (the primary appearance, the absence of author's conjectures) is found out, which is an essential factor for restoration and restoration works of art and cultural studies. Conclusions. The analysis of works of art dedicated to the Bogdanov temple in the Sabbotov shows that the engraving by A. Osipov and the watercolor by T. Shevchenko most accurately convey the original appearance of the building. Besides, they demonstrate the particular style of this architectural monument, which was formed based on rethinking the local traditions of temple construction under the influence of Western European baroque, as well as the defense needs of the time. Thus, as a monument to the hetman of Bohdan Khmelnytsky, the Church of the Elias has attracted artists and historians since the late 18th century. The tragic fate of the Ukrainian helmsman not only aroused interest in this temple but also determined the mood of transmission of this monument. Of particular interest are the works of O. Osipov and T. Shevchenko, since the accuracy of the image was the goal in both cases. I want to emphasize that due to the historical status of the Temple of Elias, not only did the magnificent engravings and watercolors appear but also began, without end, the formation of unique architectural stylistics, which was fixed in the works of painting. After all, even in the face of constant hostilities, Ukrainian hetmans XVII-XVIII centuries tried to decorate their residences with architecture worthy of a European city. This is perhaps why the wandering European artists did not leave the Church of Elijah without their attention.

Key words: temple, baroque, image, engraving, watercolor.

Актуальність теми дослідження. Важко крізь віки шукати історичної правди в тому вирі подій, свідки яких майже не залишили достовірних свідчень, а те що лишили було знищене ворожою поталою. І як важливо берегти ті артефакти, котрі не тільки не дають забути минувшину, але й збурюють значний інтерес та уяву до долі українського народу. Архітектурні пам'ятки то добряче пошарпані часом, то майже покладені долу є неоціненними свідками щодо культурного та мистецького розвитку нашого народу. І як би не подвижництво окремих людей, важливі пам'ятки нашої історії могли б також канути у лету. I Іллінська церква у легендарному Суботові була важко відвойована у державної комісії священиком Романом Орловським, котра готувала присуд про її знищення в 60-х роках XIX століття.

У рятуванні цієї святині, не усвідомлюючи цього, взяли участь ряд художників, граверів і навіть етнографів, котрі, окрім двох (Т.Шевченка, С.Васильківського), були іноземцями, доводячи важливий фракт цінності Іллінської церкви. Проявляючи в різний час інтерес до цієї будівлі, часто у контексті подорожей Україною - військовий інженер з Ельзасу, художник Йоган Генріх Мюнц, росіяни професор, художник П. Сплетссер та гравер О.Осипов, французький лікар та етнограф, що після полону не забажав повертатися до Франції, Домінік П'єр де ля Фліз, польський гравер К. Пржичиховський - усі вони своїм інтересом підкреслювали культурно-мистецьку цінність цього храму, полишаючи його образ на своїх гравюрах чи малюнках. Звичайно, що одним з найцінніших творів можна вважати акварель Т.Шевченка “Богданові руїни у Суботові”, 1845p., адже автор не тільки досконало опанував рисунок i живопис у Петербурзькій академії мистецтв, але й отримав ґрунтовні знання і з архітектури.

Важливо, що на твори живопису (здебільшого на гравюру О.Осипова, акварель Т.Шевченка) опирались дослідники-історики, археологи, архітектори, коли реставрували зруйновану Іллінську церкву чи досліджували залишки замчища-резиденції у Суботові. Перші реставраційні роботи проводились у проміжку 1862-1869 рр. під керівництвом відомого дослідника і знавця старожитностей, професора Київської духовної академії Теофана Лебединцева. Тоді керувалися порадою М.Максимовича, точнісінько орієнтуватися на гравюру О.Осипова, розміщену в книзі Д.М.Бантиш-Каменського “Історія Малой Росії” 2-е видання. У післявоєнний час XX століття на твори образотворчого мистецтва опиралися архітектори Г.Логвин, В.Мойсеєнко, В.Самойлович, П.Юрченко, Д.Яблонський, М.Цапенко.

Мета дослідження. Важливо означити певні мистецтвознавчі особливості живописних творів 3 зображенням Іллінської церкви в Суботові, що належать зарубіжним та вітчизняним художникам XVIII - початку XX століть.

Аналіз досліджень і публікацій. Більшість досліджень Світо-Іллінської церкви стосуються її архітектурного чи історичного значення, в котрих художні роботи використовуються як джерела інформації (В.Гугля, Н.Кукса, С.Кілессо). Є ряд досліджень, де зображення богданового храму аналізуються в контексті творчості художників (І.Гавліч, Ю.Мицик, О.Ніколаєв, І.Огієвська, Л.Прибєга).

Основний виклад матеріалу. Селище Суботів, що знаходиться на правому березі річки Тясмин (притоки Дніпра), у часи Богдана-Зиновія Хмельницького разом з м. Чигирин (розміщене за 7 км) було гетьманською резиденцією. На початку XVII ст. хутір Суботів став власністю козацького сотника Михайла Хмельницького, за часів якого тут виникає дерев'яний двір. Після його загибелі у 1620 році син Богдан будує тут палац-фортецю (будівництво тривало по 1648), що стала його резиденцією і в такій якості проіснувала до 1664 року. У 1664 році загони Стефана Чарнецького напали на селище та знищили його. Окрім того поглумилися над прахом гетьмана Богдана (був похований у Іллінській церкві 1657p.) та його сина Тиміша (був похований у Михайлівській церкві 1653p.).

За часів Богдана Хмельницького Суботів перетворюється у осередок культури. Гетьман володів великою бібліотекою. Освіченість гетьмана вимагала достойного облаштування. Окрім Києва, він навчався у польському м. Ярославці, у ієзуїтів, де отримав гарні знання з латинської мови. Вибагливість Богдана-Зиновія відобразилась і в архітектурі, зокрема Іллінського храму. 
Вважається, що Суботівський замок не надто різнився від багатьох інших, котрі можна було зустріти на пограниччі з Диким Полем. Його дерево-земляні укріплення були розраховані на відбиття татарських нападів. На території знаходилися казарми, кам'яниця (будинок гетьмана), два храми дерв'яний Михайлівський та кам'яний Іллінський, розташовані навпроти, господарські будівлі (наприклад, млин).

На Тиміша Хмельницький покладав великі надії, мабуть, мріяв що останній доведе до завершення розпочату ним справу. Однак, отримавши важке поранення, у грудні 1653 року Тиміш Хмельницький був похований у Михайлівській церкві. За спогадами подорожуючого Павла Алеппського (у 1656 р.), якого проводила молода дружина-вдова гетьманича Розанда, у цій церкві були зібрані скарби вірменських церков, котрі були пограбовані і зруйновані покійним Тимофієм у Сучаві. Над гробницею Тимофрія, за місцевим звичаєм, висіла велика хоругва, на якій був написаний досить схожий портрет героя верхи на коні. Тиміш був зображений з мечем у правій руці і з булавою у лівій, а на передньому плані промальована Молдавія, як країна, котру він хотів завоювати. На жаль, Михайлівська дерев'яна церква не зберіглась, як і ті цінні артефакти, котрі у ній перебували.

Одна із окрас Суботова - кам'яна Іллінська церква, збудована у 1653році. Вона вважається зразком українського бароко. Дзвіниця, що поруч, була збудована у 1869 році, по завершенню першої серйозної реставрації храму.

На відміну від храмів “козацького бароко”, у її архітектурі (плані, фронтонах) дійсно відчувається вплив барокового стилю, у якому будувалися в той час польські костели як безпосередньо на території Польщі, так і у полонізованих українських містах (наприклад, костел у м. Летичів). У свою чергу, в архітектурі багатьох польських костелів проглядається вплив церкви Іль-Джезу, що у Римі (арх. Віньола та Джакомо делла Порта). B Іллінській церкві можна також побачити два високих фрронтони з Sподбіними вигинами, один з яких з заходу виділяє головний портал, вхід до храму, а інший, зі сходу, височіє над апсидою. Цікавим є використання круглих вікон: чотири невеликих в алтарі та одне над дверима західної стіни. Фронтони оздоблені ще й сліпими вікнами.

У плані церква має умовну форму базиліки чи продовгуватого прямокутника, що було характерно для тогочасних костелів. Алтар знаходиться в апсиді, котра має ззовні і зсередини шість граней. Церква покрита коробовим склепінням і має двосхилий дах.

Заслуговує на увагу творчий підхід будівничих Іллінського храму, які зуміли переосмислити архітектуру польських тогочасних костелів та застосувати окремі прийоми до канонічних вимог православного зодчества.

Ще одною надважливою характеристикою Іллінського храму є її оборонний характер, що було властивим для тогочасної архітектури України. Церква була оснащена амбразурами, має товсті стіни, що скупо прорізані вікнами, грановану апсиду. Під час військової небезпеки, вона ставала військовим об'єктом.

Над серединою церкви височіє глава, котра видозмінювалася. Першої руйнації гарматним пострілом верх церкви зазнав через Юрія Хмельницького, що шукав гроші батька [3; 20]. У 1678 році, коли турки зруйнували Чигирин, перестав існувати на деякий час і Суботів. Жителі почали повертатися тільки на початку XVIII ст. Можливо тоді з'явилася маківка, котра зображена на гравюрі О.Осипова.

Цікавим фрактом, який доніс до нас Павло Алеппський, стало використання у будівництві Іллінського храму величезних каменів, котрі привезені після руйнації мечеті гетьманом Богданом з татарського міста, що було неподалік. Розміри їх викликали подив у подорожуючого.

Тільки нещодавно збудувавши Іллінську церкву, як вже у 1657 році Богдан Хмельницький був там упокоєний. Як зазначалось, гробниця не вціліла.

У XVIII ст. Іллінська церква погано утримувалася і була дуже бідною, тому стала цвинтарною. Кам'яні хрести можна побачити на всіх творах художників, окрім акварелі С.Васильківського.

Як раз у 80-х роках XVIII ст. Йоган Генріх Мюнц (1727-1798рр.), народжений в Ельзасі, здійснюючи подорожі Україною, побував у Суботові. Він зробив рисунок “Богданів млинок” у 1783 році, який потім долучив до колекції акварелей “Мальовнича подорож по Польщі і Україні”. Юрій Мицик, котрий звернув увагу на цього художника, інженера, у своїй статті наводить цікаві роздуми Мюнца щодо інтересу до водяного млина у Суботові: “Цей млин був первісною причиною бунту козаків у 1647 році... Бунту, який струснув підвалини Корони Польської за панування короля Яна Казимира" [7].

Мюнц протягом 1781-1783 років здійснив три подорожі Україною, коли був на службі у короля Станіслава Августа Понятовського. За матеріалами подорожей, створив кілька альбомів, а в Корсуні заклав палац та парк. Як вважає Ю.Мицик, Мюнц зробив в Україні 217 оригінальних малюнків (зображення міст, замальовував корчми, селянські двори, митниці, прикордонні знаки, млини тощо) і ще кілька десятків копій. Малював він олівцем і пером, а також аквареллю. Замальовки супроводжував коментарями. Художній спадок Мюнца хоч і зберігся, але значна частина його знаходиться у Москві та Варшаві.

Безпосередньо зображення Іллінської церкви вперше відтворене у гравюрі О.Осипова "Вид Іллінської церкви в Суботові і руїни дому Богдана Хмельницького”, 1826р. (рис. 1). Гравюра зроблена на основі рисунка П.Сплесстера, московського іноземця-професора. Замовником цього зображення був Д.М.Бантиш-Каменський, котрий проявляв значний інтерес до української історії. 


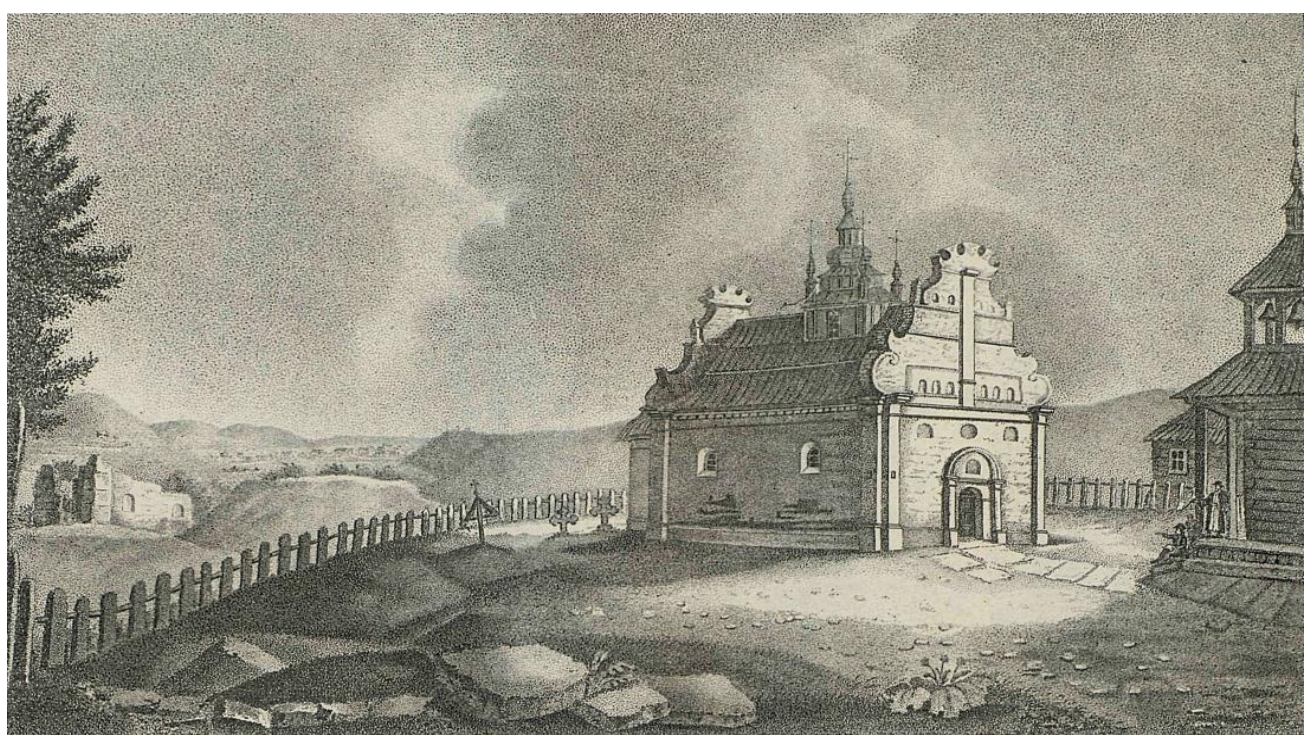

\section{Рис.1. О.Осипов на основі рисунка П.Сплесстера. Вид Іллінської церкви в Суботові і руїни дому Богдана Хмельницького». 1826р. Гравюра}

Відомо, що Олексій Агапович Осипов (гравер при музеї Московського університету з 18151834 p.), котрий навчався малюнку у Ф.Кюнеля та гравіруванню у академіка М.І.Соколова в Москві, багато гравірував для видавництва П.П.Бекетова. Відзначають, що портрети його роботи вирізняються великою схожістю. Для Д.Бантиш-Каменського було важливо, щоб історичні пам'ятки його дослідження були дуже достовірними. Дослідник вперше здійснив архітектурну характеристику церкви, вбачаючи у ній неоціненну пам'ятку козацьких часів як усипальниці гетьмана. Тому відразу ж після свого візиту відрядив художника. I до нині це зображення не втрачає мистецької та історичної цінності.

Хоча Д.Бантиш-Каменський не вплинув жодним чином на покращення стану Іллінської церкви, яка на той час активно руйнувалася, та він підготував та посилив до неї значну увагу.

Неоціненний вклад у мистецьку спадщину зробив Т.Шевченко, котрий став співробітником урядової Київської археографрічної комісії, створеної у 1843 році. Метою роботи комісії було наступне завдання - довести, що Правобережна Україна не польський, а руський край. Молодий художник багато подорожував Україною, збирав фольклорні й етнографічні матеріали, замальовував історичні й архітектурні пам'ятки.

На думку більшості біографів, Т.Шевченко не мав змоги зупинитися на Чигиринщині надовго, через надто напружений ритм життя, тому працював швидко. Завдяки поїздці виникають неперевершені роботи художника, серед яких “Богданові руїни у Суботові" (папір, акварель), 1845p., де ліворуч чорнилом є власноручний напис автора (рис.2).

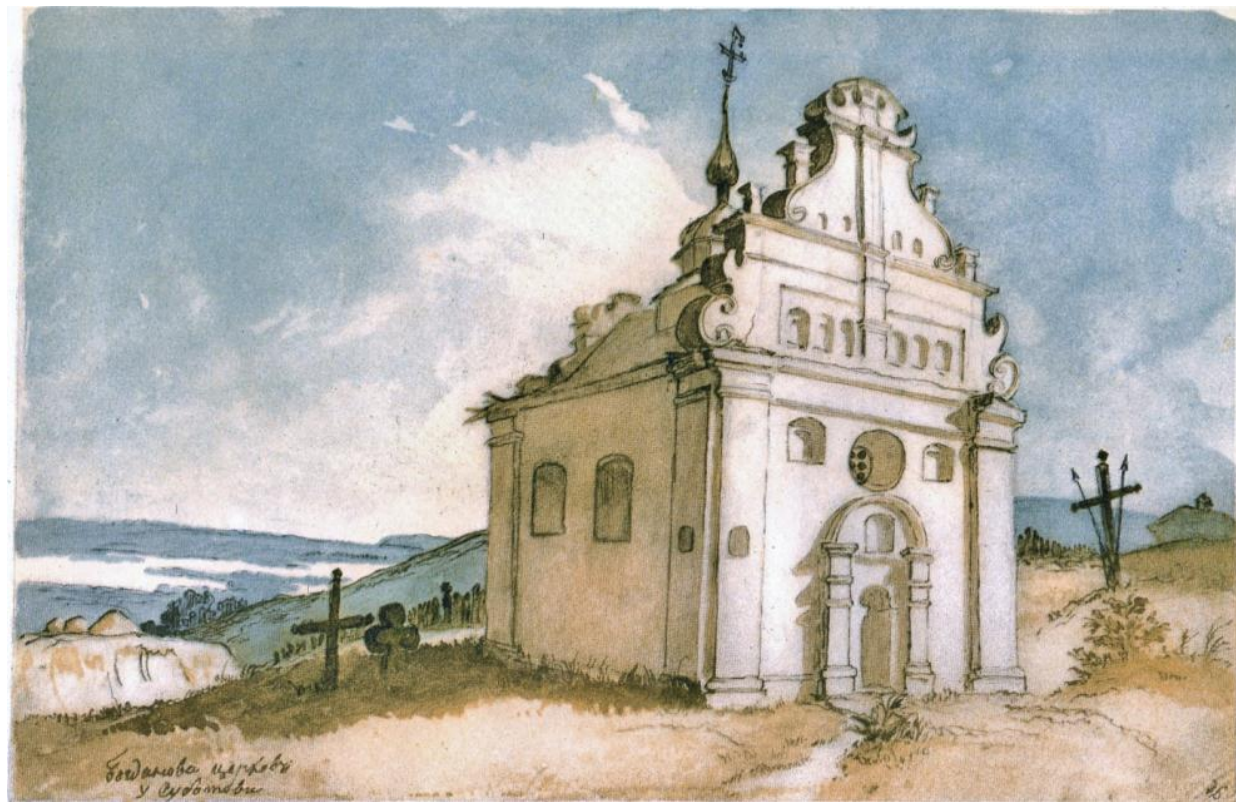

Рис.2. Т.Шевченко. Богданові руїни у Суботові. 1845p. Папір, акварель 
Замальовки чисельних пам'яток Т.Шевченко виконував у техніці акварелі, яку успішно застосовував під час навчання у Петербурзькій академії мистецтв. "Становлення Тараса Шевченка як аквареліста, безумовно, відбувалося під впливом вчителя Карла Брюллова. Вплив К.Брюллова: певна ідеалізація зображуваного, романтична піднесеність, деяка умовність колориту. Для акварелей Т.Шевченка, виконаних упродовж 1845 року, характерним є нанесення рисунка олівцем. Колористична гама - стримана, із застосуванням переважно коричневих та блакитних тонів. Гортаючи сторінки альбому 1845 року, з яким художник подорожував з весни до осені, переконуємося у надзвичайному захопленні і зацікавленості Т.Шевченка архітектурною спадщиною, помічаємо ретельну прорисовку об’єктів, прагнення якомога точніше передати пластичні якості форми споруд" [10; 80].

Особливістю робіт Т.Шевченка, як зазначають дослідники, є використання на тлі пам'яток ознак убогості, занедбаності, властивих закріпаченим селам. От і богданова церква має зарослий бур'яном двір, тріщини покривають стіни знакової будівлі і красномовні хрести височать над місцем колишньої слави.

"Як самодостатні мистецькі твори, малюнки Т.Шевченка із зображеннями архітектурних пам'яток становлять неабияку наукову та історичну цінність. І в наш час вони знаходять практичне застосування у пам'яткоохоронній практиці - як іконографічний матеріал" [10; 86]. В окремих випадках роботи Т.Шевченка стали єдиним взірцем для їх реставрації.

Наступним, хто проявив інтерес до Суботова та його пам'яток, був Домінік П'єр де ля Фліз, чи Дем'ян Петрович Фліз (1787-1861), котрий хоч і був французом, але після полону не забажав повертатися. За освітою він був лікар, але надзвичайно цікавився етнографічними дослідженнями побуту українців. Розпочав свої дослідження де ля Фліз в 1845 році, згідно програми Російського географічного товариства. Результатом його праці стали дев'ять рукописних альбомів, котрі стосувалися різних аспектів культури та побуту українців. Серед виконаних французьким дослідником рисунків привертає увагу “План палацу Богдана Хмельницького в с.Суботові”, 1854 року. І хоча робота свідчить, що її виконавець непрофесійний художник, та теж фокусує увагу глядача на архітектурних деталях будівлі Іллінської церкви - фрігурних фронтонах та стрімкоспрямованій маківці.

Трагедія руйнації Іллінської церкви сповна проглядається у гравюрі польського художника К.Пржичиховського “Свято-Іллінська церква в Суботові”, 1861р. Однак, саме в цей час о.Роман (Орловський) розпочинає важку справу по відновленню занепалої святині. Протягом десяти років (18521862 рр.) він домагався позитивного вирішення проблеми, адже одна з комісій постановила знищити пам'ятку. Стан пам'ятки був катастрофрічним.

Священик, усвідомлюючи історичне значення церкви, намагався максимально відродити її первісний вигляд. Саме за порадою Михайла Максимовича під час відновлення користувалися гравюрою О.Осипова. Відновлена Іллінська церква була освячена 30 вересня 1869 року.

Інтерес до українських старожитностей проявляв художник С.Васильківський, відомий представник вітчизняної пейзажної школи. Майстер багато запозичив у барбізонців, зокрема, шанував надзвичайно К.Коро за м'яку манеру письма та перейняв прийоми зображення туману в останнього.

Сергій Васильківський, як митець-етнограф, замальовував старовинні церкви, українських селян. Заради цього він мандрував Харківщиною та Полтавщиною, подорожував по Дніпру та Запоріжжям. Побував художник і в Галичині, зробивши чимало фротографічних знімків зі старих будівель та церков. Отримані етнографічні матеріали Сергій Іванович представив на археологічному з"їзді у Харкові в 1902 році. Адже він був одним з фундаторів Харківського літературно-художнього гуртка, де заснував український архітектурно-мистецький відділ і був його головою до самої смерті (1917р.). Цей відділ зібрав багато матеріалу по українському будівництву.

1900 року Сергій Іванович разом з проф. С.М.Самокішем склали альбом “Із української старовини", до якого текст написав російською та французькою мовами Д.І.Яворницький. В серії акварелей "Старовинні українські церкви”, 1900 року є робота “Церква святого Іллі в Суботові поблизу Чигирина, 1663p. ", папір, акварель.

Іллінська церква зображена пізнім вечором, місячне проміння освітлює цю важливу будівлю, огорнуту туманом. Як відзначає Д.Горбачов, С.Васильківський полюбляв пору, коли сонце сідало і пітьма потроху насувалася на природу. Така атмосфера немов би наголошує на славній минувшині цього храму та, водночас, лишає враження смутку та ностальгії.

Багато дослідників ставлять під сумнів, що вказана робота була виконана з натури. Надто схожа вона з гравюрою О.Осипова, 1825 року. Дзвіниця зображена дерев'яною, хоча її виклали 3 цегли ще у 1874 році. Відсутні також хрести, розміщені на подвір'ї.

Висновки. Отже, Іллінська церква саме як пам'ятка гетьманства Богдана Хмельницького притягувала художників та істориків ще з кінця XVIII ст. Трагічна доля українського керманича не тільки викликала інтерес до цього храму, але й визначала настрій передачі цієї пам'ятки. Особливий інтерес становлять роботи О.Осипова та Т.Шевченка, так як достовірність зображення була метою в обох випадках. Хочеться наголосити, що завдяки історичному статусу Іллінського храму не тільки з'явилися чудові гравюри та акварелі, але й розпочалось, не закінчившись, формування особливої архітектурної стилістики, котра, власне, й зафіксована у творах живопису. Адже навіть в умовах постійних воєнних дій, українські гетьмани XVII-XVIII ст. намагалися свої міста-резиденції прикрасити архітектурою гід- 
ною європейського міста. Можливо саме тому мандрівні європейські художники не полишали Іллінську церкву без своєї уваги.

\section{תimepamypa}

1. Бантыш-Каменский Д.Н. История Малой России. Ч.1. От водворения славян в сей стране до присоединения оной, в 1654 году, к Российскому государству царем Алексеем Михайловичем. Москва: тип. Семена Селивановского, 1830. 470 с

2. Гавліч І.Б. Художня спадщина Тараса Шевченка. Психологія і суспільство: укр. теорем.-метод. соціогуманіт. часоп. Тернопіл. держ. екон. ун-т. Тернопіль: [б. в.], 2014. С. 93-94.

3. Гугля В.І. Суботів Хмельницьких. Дніпропетровськ: Інститут суспільних досліджень, 2006. 61с.

4. Де ля Фліз Д. Альбоми: в 2 т. Київ: НАН України, Ін-т укр. археографії та джерелознавства імені М.С.Грушевського, 1996. Т.1. 244с.

5. Кукса Н.В. Іллінська церква в Суботові в студіях XIX - початку XX ст. Пам'ятки України, 2011. № 5-6.

6. Кілессо С. Архітектурні і мистецькі скарби Богданового краю. Київ: Техніка, 2000. 142с.

7. Мицик Ю.А. Мюнц Жан-Анрі. Енциклопедія історії України: у 10т. [редкол.: В.А. Смолій (голова) та ін.]. Київ: Наукова думка, 2010. Т.7. С. 142.

8. Ніколаєв О. Сергій Васильківський: життя і творчість. Харків: Пролетарий, 1927. 39с.

9. Огієвська І.В. Сергій Іванович Васильківський. Київ: Наукова думка, 1980. 166 с.

10. Прибєга Л. Архітектурні старожитності України очима Тараса Шевченка. Українська академія мистецтва: дослідницькі та науково-методичні праці. Київ: НАОМА, 2013. Вип. 21. С.74-86.

11. Павлуцкий Г.Г. Деревянные и каменные храмы. К.: $1905 . \quad$ C.111-116. URL: https://www.myslenedrevo.com.ua/ru/Sci/Heritage/Pavlucki/Subotiv.html.

\section{References}

1. Bantysh-Kamensky, D. (1830). History of Little Russia. M. [in Russian].

2. Gavlich, I. (2014). Taras Shevchenko's artistic heritage. Psychology and Society. T. [in Ukrainian].

3. Gugla, V. (2006). Khmelnitsky Subbotts. D. [in Ukrainian].

4. De la Flis, D. (1996). Albums: in 2 t. K. [in Ukrainian].

5. Kuksa, N. (2011). Ilyinskaya church in the Sabbath in the studios of the nineteenth and early twentieth centuries. Sights of Ukraine, No. 5-6. K. [in Ukrainian].

6. Kilesso, S. (2000). Architectural and artistic treasures of Bogdanovsky edge. K. [in Ukrainian].

7. Mycyk, J. (2010). Jean-Henry Münster. Encyclopedia of Ukrainian History: 10th. K. [in Ukrainian].

8. Nikolaev, O. (1927). Sergei Vasylkivsky: life and work. K. [in Ukrainian].

9. Ogievska, I. (1980). Sergei Ivanovich Vasylkivsky. K. [in Ukrainian].

10. Pribega, L. (2013). Architectural antiquities of Ukraine by the eyes of Taras Shevchenko. Ukrainian Academy of Arts: research and methodological works, 21. K. [in Ukrainian].

11. Pavlucky, G. (1905). Wooden and stone temples. K. [in Ukrainian]. Retrieved from: https://www.myslenedrevo.com.ua/ru/Sci/Heritage/Pavlucki/Subotiv.html

Стаття надійшла до редакції 27.04.2019 р. 